\title{
PENGARUH FAKTOR FUNDAMENTAL TERHADAP PENILAIAN SAHAM PADA PERUSAHAAN MANUFAKTUR YANG TERDAFTAR DI BURSA EFEK INDONESIA
}

\author{
Muthia Harnida \\ E- mail: raissa_kembar@yahoo.co.id
}

Universitas Islam Kalimantan (UNISKA) MAB Banjarmasin

\begin{abstract}
The approaches of stock valuation can be used by the investor using the approaches of present value and price earnings ratio. This research is to investigate the effect of fundamental analysis on the stock valuation using the approach of price earnings ratio. The fundamental factor uses some variables such as dividend yield, return on assets, leverage, firm size and growth of earnings per share. The sample is manufacturing companies listed in Indonesian Stock exchange for the period of financial report of 2013 until 2015.

The result indicates that statistically dividend yields, leverage, firm size, and return on assets have significant effect on the stock valuation of price earnings ratio, but growth of earnings per share does not affect the stock valuation.
\end{abstract}

Key words: Fundamental factor, stock valuation, price earnings ratio, dividend yields, leverage, firm size, return on assets, growth of earnings per share.

\section{PENDAHULUAN}

Penilaian saham dapat

dilakukan melalui pendekatan present value dan pendekatan price earnings ratio

. Pendekatan dengan menggunakan present value adalah dengan menaksir nilai intrinsik saham biasa perusahaan dengan menentukan nilai sekarang dari aliran kas yang diharapkan diperoleh di masa yang akan datang. Dasar yang digunakan untuk menentukan nilai sekarang dari suatu saham yang dinilai adalah tingkat bunga tertentu yang dianggap layak oleh investor. Sedangkan pendekatan price earning ratio menggunakan angka rasio harga per lembar saham dengan pendekatan per lembar saham dari laporan keuangan perusahaan.

Pendekatan price earning ratio lebih praktis daripada pendekatan present value, karena tidak mempertimbangkan informasi tingkat bunga yang kadang-kadang sulit disinkronkan dengan periode laporan keuangan perusahaan. 
Beberapa riset yang meneliti tentang variabel yang berpengaruh terhadap penilaian saham melalui pendekatan price earnings ratio menggunakan beberapa variabel tingkat pertumbuhan laba, dividend payout rate dan deviasi standar tingkat pertumbuhan laba sebagaimana yang diteliti oleh Whitbeck dan Kisor (1963) dalam Mangku (2001). Malkiel dan Cragg (1968), dalam Anugerah dkk (2001) melanjutkan riset yang telah dilakukan oleh Kisor dengan menambahkan beta sebagai variabel independen. Hasil penelitian Anugerah, dkk (2001), menunjukkan bahwa terdapat korelasi negatif antara price earnings ratio dengan return saham, tingkat pertumbuhan juga menunjukkan hubungan yang negatif. Sedangkan arah korelasi yang diperoleh antara price earnings ratio dengan dividend payout ratio dan standard deviasi menunjukkan arah yang positif.

Hasil-hasil penelitian terdahulu masih memberikan hasil yang belum konsisten factor-faktor apa saja yang memengaruhi penilaian saham dengan menggunakan pendekatan price earnings ratio. Penelitian yang sekarang menggunakan beberapa variabel antara lain dividend yield, return on asset, leverage, firm size dan earnings per share.

\section{TINJAUAN PUSTAKA}

Foster (1986) menjelaskan tentang analisis fundamental yang mengasumsikan tiap sekuritas memiliki nilai intrinsik yang dapat ditentukan atas dasar unsur fundamental, seperti earnings, dividends, capital structure dan growth potential. Kieso, weygandt (2001), menyebutkan faktor-faktor yang ikut berkontribusi terhadap perbedaan price earnings ratio adalah relative risk, stability of earnings, trend in earnings dan persepsi pasar terhadap company's growth potential. Teori sinyal (Signalling theory) adalah salah satu teori normatif yang juga mendasari penelitian tentang penilaian saham dengan menggunakan price earnings ratio. Teori ini terkait dengan information asymetry.

$$
\text { Studi Gonedes }
$$

menyatakan bahwa angka-angka akuntansi yang dilaporkan pihak manajemen dapat digunakan sebagai sinyal jika angka tersebut dapat mencerminkan informasi tentang sifat keputusan perusahaan yang 
unobservable. Asimetri informasi dapat terjadi di pasar modal jika manajemen tidak menyampaikan semua informasi yang diperolehnya secara penuh tentang semua hal, yang dapat memengaruhi nilai perusahaan yang akan terefleksi pada perubahan harga saham, karena pasar akan merespon informasi yang ada sebagai sinyal, maka saham yang diperdagangkan dapat overvalued atau undervalued.

Harianto dan Sudomo (1998) menyatakan bahwa dalam membuat model peramalan harga saham, langkah yang penting adalah mengidentifikasikan faktor-faktor fundamental seperti kebijakan dividen, pertumbuhan penjualan, dan biaya, yang diperkirakan memengaruhi harga saham. Faktor fundamental tersebut secara teori diduga berpengaruh terhadap harga pasar saham maupun terhadap penilaian saham.

Gordon dan Litner (1963) dalam Nugraheni (2001) mengemukakan bahwa akibat dari investor menilai dolar dari dividen yang diharapkan lebih tinggi daripada dolar yang diharapkan dari capital gains menyebabkan komponen dividend yield risikonya menjadi lebih rendah dari komponen growth pada persamaan return total saham, jadi semakin tinggi laba yang ditahan untuk meningkatkan pertumbuhan maka para investor mengganggap bahwa risiko ketidakpastian capital gains yang diharapkan semakin besar.

Kebijakan dividen tersebut bisa dinilai dari besarnya dividend yield. Dividend yield diharapkan berkorelasi tinggi dengan pergerakan harga saham. Jika dividend yield tinggi maka harga saham cenderung naik mengikutinya, demikian sebaliknya, sehingga dari uraian tersebut dapat dikembangkan sebuah hipotesis yakni:

H1: Dividend yield berpengaruh terhadap penilaian saham.

Return on assets menunjukkan seberapa efektif perusahaan memanfaatkan dana dari pemilik, kreditur dan sumber lainnya untuk kepentingan perusahaan. Semakin tinggi rasio 
ini, maka makin profitable perusahaan secara relatif (Foster, 1986). Tinggi rendah pertumbuhan laba periode berikutnya sangat tergantung pada tinggi rendahnya return on assets (ROA) setelah dividen diperhitungkan. Disamping itu, return perusahaan yang cukup tinggi dengan tingkat risiko tertentu yang relatif rendah dapat memengaruhi optimisme investor terhadap prospek earnings perusahaan yang pada akhirnya berpengaruh terhadap price earnings ratio.

Dari uraian di atas dapat dikembangkan sebuah hipotesis yakni:

$\mathrm{H} 2$ : Return on assets berpengaruh terhadap penilaian saham .

$\begin{array}{lll} & \text { Peningkatan } & \text { hutang } \\ \text { dapat berpengaruh positif }\end{array}$
terhadap prospek pertumbuhan earnings di masa yang akan datang, sepanjang poenambahan hutang tersebut mampu menghasilkan return yang lebih tinggi dari biaya hutangnya, [Modigani \& Miller (1963) dalam Watts \& Zimmerman (1986)] Leverage suatu perusahaan akan memengaruhi harapan investor terhadap kemampuan perusahaan untuk menghasilkan earnings di masa yang akan datang, yang akhirnya berpengaruh terhadap penilaian saham, sehingga dapat dikembangkan sebuah hipotesis bahwa:

H3: Leverage berpengaruh terhadap penilaian saham .

Total asset yang dimiliki perusahaan dapat meningkatkan kemampuannya untuk mendanai investasi-investasi yang menguntungkan. Namun ada juga pandangan investor bahwa semakin besar ukuran perusahaan maka semakin mungkin perusahaan memanfaatkan peluang investasi sehingga pertumbuhan earnings yang dicapai akan diikuti pula oleh kenaikan risiko, akibatnya investor yang tidak menyukai risiko akan menaikkan tingkat pengembalian yang diinginkan terhadap saham perusahaan sehingga dapat menurunkan harga saham tersebut dan selanjutnya akan berpengaruh terhadap price earnings ratio. 


Penilaian investor
tentang kemampuan perusahaan
berskala besar menghasilkan return
yang lebih besar dibandingkan
dengan perusahaan yang berskala
kecil masih menjadi kontroversi,
terbukti dari beberapa penelitian
masih menemukan adanya
anomali bahwa perusahaan
berskala justeru
menghasilkan return yang lebih
besar (Watts \& Zimmerman, 1986).
Dari uraian di atas dapat
dikembangkan sebuah hipotesis
yakni:

H4 : Firm size (Ukuran perusahaan) berpengaruh terhadap penilaian saham .

Harga saham
merefleksikan harapan pasar
terhadap earnings sehingga
tingkat pertumbuhan earnings
berpengaruh terhadap price
earnings ratio. Jones (1998)
menjelaskan bahwa perusahaan
yang dipercaya oleh pasar akan
mencapai tingkat pertumbuhan
earnings lebih tinggi cenderung
akan dinilai lebih tinggi dari pada
perusahaan yang menunjukkan

harapan tingkat pertumbuhan earnings yang lebih rendah. Selanjutnya faktor utama yang dapat menjelaskan penyebab perbedaan price earnings ratio antar perusahaan adalah harapan pertumbuhan earnings perusahaan di masa yang akan datang. Jadi dapat disimpulkan bahwa tingkat pertumbuhan earnings berpengaruh positif atau negatif terhadap penilaian saham dengan menggunakan pendekatan price earnings ratio tergantung pada optimisme dan pesimisme ekspektasi pasar terhadap pertumbuhan earnings perusahaan pada masa yang akan datang.

Dari uraian di atas dikembangkan hipotesis yakni: H5 : Pertumbuhan earnings per share berpengaruh terhadap penilaian saham .

\section{METODA PENELITIAN}

\section{Jenis Penelitian}

Penelitian ini adalah penelitian kuantitatif untuk menguji analisis fundamental dengan 
menggunakan variable-variabel dividend yield, return on assets (ROA), leverage, firm size, dan pertumbuhan earnings per share terhadap penilaian saham dengan menggunakan price earnings ratio.

\section{Populasi dan sampel}

Populasi dalam penelitian ini adalah perusahaan manufaktur yang terdaftar di Bursa Efek Indonesia yang sahamnya diperdagangkan secara aktif selama periode pengamatan yakni periode 2013 sampai dengan 2015. Dari populasi tersebut diperoleh sampel perusahaan sebanyak 40 perusahan dengan periode 3 (tiga) tahun pengamatan secara purposive sampling dan akhirnya diperoleh data sebanyak 120.

\section{Jenis dan Sumber Data}

Penelitian ini menggunakan data sekunder yang diperoleh dengan mengunduh data melalui Indonesian Stock Exchange (ISX).co.id. untuk periode 20132015.

\section{Definisi Operasional dan}

\section{Pengukuran Variabel}

Price earnings ratio menurut Brigham \& Gapenski (1996), menunjukkan besarnya harga yang bersedia dibayar oleh investor untuk tiap dollar laba yang dilaporkan oleh perusahaan. Jika price earnings ratio digunakan untuk menunjukkkan price earnings ratio pada periode $\mathrm{t}, \mathrm{P}_{\mathrm{t}}$ untuk harga saham per lembar pada periode $t$ dan EPS merupakan laba per lembar biasa periode $t$, maka diperoleh rumus untuk menghitung Price earnings ratio, yaitu:

$$
P E R_{t}=P_{t} / E P S
$$

Karena laporan keuangan aktual akhir Desember tiap tahun baru keluar akhir Maret maka data harga $\left(\mathrm{P}_{\mathrm{t}}\right)$ diambil dari harga penutupan bulan April tahun $\mathrm{t}+1$. Price Earnings ratio merupakan variabel terikat atau atau variable dependen yang diduga akan dapat dijelaskan oleh lima (5) variabel bebas. Variabel-variabel bebas tersebut terdiri dari:

a. Dividend yield, adalah komponen income dari stock's return yang dinyatakan atas dasar prosentase: 
Div Yield $=D P S_{t} / P_{t} x 100 \%$

Dalam hal ini $D P S_{t}$ adalah dividen per saham dan $P_{t}$ adalah harga saham saat penutupan.

b. Return on Assets, dapat dihitung dengan menggunakan rumus berikut (Foster, 1986):

Net Income thn ket

ROAt

Total Assets (average) thn ke-t

c. Leverage, ukuran standarnya adalah total hutang dibagi dengan ekuitas (Foster, 1986). Dalam penelitian ini leverage dihitung dengan rumus sebagai berikut:

$$
L e v_{t}=D t / T A_{t}
$$

$L E V_{t}$ adalah leverage pada tahun $\mathrm{t}$, $D_{t}=$ total hutang pada ke $\mathrm{t}$ dan $T A_{t}=$ total asset pada tahun ke $t$.

d. Ukuran perusahaan (firm size), dilihat dari total asset yang dimiliki.
(2001) mengemukakan bahwa ukuran perusahaan dapat diukur dengan menggunakan log dari total asset tiap perusahaan tiap tahun, Digunakannya $\log$ total asset adalah untuk mendapatkan pengaruh linier dari total asset yang kalau diantilogkan akan menjadi tidak linier setelah mencapai titik tertentu. Dalam bentuk persamaan dapat dinyatakan:

$$
\text { Size }_{t}=\log (\text { total asset }) t
$$

e. Pertumbuhan Earnings Per Share (EPS), pertumbuhan earnings dapat dilihat dari pertumbuhan EPSnya yang dihitung dengan rumus berikut:

$$
\text { EPSt }-E P S_{t-1}
$$

Tingkat Pertumbuhan EPS =

$$
E P S_{t-1}
$$

$E P S_{t}=$ EPS pada tahun yang dihitung tingkat pertumbuhannya dan EPS $\mathrm{t}_{\mathrm{t}-1}=\mathrm{EPS}$ pada tahun sebelumnya.

\section{Pengujian Asumsi Klasik}

Sebelum melakukan pengujian hipotesis, terlebih dahulu dilakukan 
pengujian asumsi klasik, yang meliputi uji normalitas, homoskedastisitas, dan multikolinieritas.

\section{Pengujian Hipotesis}

Pengujian hipotesis dalam penelitian ini menggunakan model regresi linier berganda (multiple linier regression method). Pengolahan data dilakukan dengan program SPSS statistik parametrik . Model persamaan regresinya adalah sebagai berikut:

Price Earnings ratio $=\alpha_{2}+\beta_{1}($ DYield $)+\beta_{2}($ ROA $)+\beta_{3}($ Lev $)+\beta_{4}(F S)+\beta_{5}($ PEPS $)+\varepsilon$

\section{HASIL PENELITIAN}

1. Deskripsi Statistik

Tabel 1: Statistik Deskriptif

Descriptive Statistics

\begin{tabular}{|l|c|r|r|r|r|}
\hline & $\mathrm{N}$ & \multicolumn{1}{|c|}{ Minimum } & \multicolumn{1}{c|}{ Maximum } & \multicolumn{1}{c|}{ Mean } & \multicolumn{1}{c|}{ Std. Deviation } \\
\hline P/E Ratio & 120 & -1.4756 & 52.0428 & 8.247856 & 8.876741 \\
\hline DYIELD & 120 & 4.6599 & 7.1287 & 5.602825 & .574670 \\
\hline ROA & 120 & -.1167 & .3997 & .122186 & $8.65647 \mathrm{E}-02$ \\
\hline LEV & 120 & .06 & 1.86 & .3746 & .1867 \\
\hline FIRM SIZE & 120 & .00 & 26.20 & 4.3230 & 5.2320 \\
\hline EPS & 120 & -2.1276 & 8.27754 & $4.75 \mathrm{E}-02$ & 1.287654 \\
\hline $\begin{array}{l}\text { Valid N } \\
\text { (Listwise) }\end{array}$ & 120 & & & & \\
\hline
\end{tabular}

Korelasi antara variabel independen terhadap variabel dependen sebagaimana yang tampak pada tabel 2 di bawah ini.

Tabel 2

Model Summary

\begin{tabular}{|l|l|l|l|l|l|}
\hline Model & R & R Square & $\begin{array}{c}\text { Adjusted R } \\
\text { Square }\end{array}$ & $\begin{array}{c}\text { Std. Error of } \\
\text { the } \\
\text { Estimate }\end{array}$ & $\begin{array}{c}\text { Durbin- } \\
\text { Watson }\end{array}$ \\
\hline 1 & .674 & .562 & .496 & 7.8942517 & 2.011 \\
\hline
\end{tabular}


a. Predictor: (Constant), DYield, ROA, Lev, Firm Size, EPS.

b. Dependent Variable: Price earnings ratio

Dari tabel 2 terlihat bahwa $R^{2}$ ( $R$ square) sebesar 0,562 , artinya variabel dividend yield, return on assets, leverage, firm size dan pertumbuhan earnings per share berpengaruh terhadap price earnings ratio sebesar $56,2 \%$, sehingga masih ada variabel variabel lain yang memengaruhinya sebanyak $44,8 \%$ di luar model penelitian ini.

Hasil pengujian hipotesis terlihat pada tabel 3 bnerikut:

Tabel 3:

Coefficients

\begin{tabular}{|l|l|l|l|l|l|l|l|}
\hline \multirow{2}{*}{} & & \multicolumn{2}{|c|}{$\begin{array}{c}\text { Unstandardized } \\
\text { Coefficients }\end{array}$} & $\begin{array}{l}\text { Standardize } \\
d \\
\text { Coefficients }\end{array}$ & \multicolumn{1}{|l|}{$\mathrm{t}$} & Sig & \\
\hline Model & & B & $\begin{array}{c}\text { Std. } \\
\text { Erro } \\
\mathrm{r}\end{array}$ & Beta & & & VIF \\
\hline 1 & (Constant) & 2.354 & 7.844 & & .304 & .762 & \\
\hline & D. Yield & -2.96 & 1.383 & .225 & 2.144 & .003 & 1.232 \\
\hline & ROA & -24.288 & 9.125 & -.385 & -3.210 & .002 & 1.259 \\
\hline & Lev & -7.829 & 2.789 & -.244 & -3.166 & .002 & 1.221 \\
\hline & Firm size & .2964 & .562 & .047 & .278 & .001 & 1.044 \\
\hline & Eps & -.427 & .152 & -.015 & -.2 .816 & .781 & 1.243 \\
\hline
\end{tabular}

a. Dependent Variable: Price earnings ratio

Hasil penelitian pada table 4 menunjukkan bahwa dividend yield berpengaruh terhadap penilaian saham dengan pendekatan price earnings ratio terlihat dari nilai $\mathrm{p}$-value 0,003 yang berada di bawah tingkat alpha 0.05, dengan demikian hipotesis yang menyatakan bahwa dividend yield berpengaruh terhadap penilaian saham dapat diterima . Pengaruh dividend yield adalah negatif . Hal ini bertentangan dengan padangan Jones (1998), yakni bila hal-hal lain tetap (konstan) maka pembagian dividen yang tinggi akan berpengaruh positif terhadap penilaian saham dengan pendekatan price earnings ratio. Berdasarkan data yang 
dianalisis pergerakan harga saham berlawanan dengan dividend yield. Jika dividend yield tinggi maka harga saham cenderung turun mengikutinya, demikian sebaliknya.

Hasil penelitian juga menunjukkan bahwa return on assets (ROA) berpengaruh signifikan dengan tingkat signifikansi atau pvalue 0,002 . Hal ini menunjukkan bahwa semakin besar ROA semakin kecil price earnings rationya terlihat dari koefisien -24,288. Variabel return on asset berpengaruh negatif terhadap price earnings ratio, dapat diasumsikan bahwa data perusahaan sampel mengindikasikan return on asset tidak dapat mencapai tingkat pengembalian yang diinginkan atau perusahaan dianggap kurang efektif memanfaatkan dana sehingga menurunkan harga saham Hasil penelitian ini mendukung penelitian Mpaata dan Sartono (1997). Leverage juga menunjukkan ada pengaruh negatif, dengan tingkat signifikansi 0,02. Artinya semakin besar leverage maka semakin kecil price earnings ratio. Leverage berpengaruh negatif terhadap penilaian saham dengan pendekatan price earnings ratio, artinya semakin tinggi proporsi hutang pada struktur modal perusahaan maka makin tinggi risiko finansial bagi investor sehingga mereka menetapkan tingkat pengembalian yang lebih tinggi untuk menilai saham perusahaan tersebut sehingga mengakibatkan rendahnya harga pasar saham dan menurunkan nilai price earnings ratio (Jones, 1998). Dengan demikian hipotesis yang menyatakan bahwa leverage berpengaruh terhadap penilaian saham dapat diterima

Dalam penelitian ini firm size secara statistik juga memengaruhi penilaian saham seperti terlihat pada tingkat signifikansinya 0,001dengan koefisien bertanda positif. Hal ini artinya menunjukkan bahwa semakin besar ukuran perusahan maka price earnings rationya juga semakin besar. Variabel ukuran perusahaan yang diproksikan dengan log total asset juga menunjukkan arti bahwa dengan 
meningkatnya total asset akan meningkatkan kemampuan perusahaan untuk meraih peluang investasi yang menguntungkan dan memberikan prospek yang lebih baik bagi peningkatan earnings di masa mendatang oleh investor. Variabel pertumbuhan earnings per share secara statistik tidak menunjukkan pengaruh terhadap penilaian saham melalui pendekatan price earnings ratio, karena tingkat signifikansinya berada di atas alpha 0,05 .

\section{SIMPULAN}

Berdasarkan hasil

penelitian dengan menggunakan analisis regresi berganda dengan melakukan analisis fundamental menggunakan beberapa variabel meliputi variabel dividend yield, return on assets, leverage dan firm size serta pertumbuhan earnings per share. Hasil penelitian menunjukkan bahwa terdapat 4 (empat) dari variabel yang dihipotesiskan memengaruhi penilaian saham melalui pendekatan price earnings ratio, yakni variable dividend yield, return on assets (ROA), leverage, dan firm size. Sedangkan variabel pertumbuhan earnings per share secara statistik hasilnya tidak memengaruhi penilaian saham. Hasil penelitian ini juga mendukung hasil-hasil penelitian sebelumnya.

\section{DAFTAR REFERENSI}

Anugerah, Nurul dkk, 2001, Korelasi Antara Price Earnings Ratio dan Return Saham pada Perusahaan Go Publik di BEJ, Simposium Nasional Akuntansi IV Bandung, IAI-KAPD.

Brigham \& Gapenski, 1996, Intermediate Financial Management, 5 $5^{\text {nd }}$, ed, Dryden Press Harcourt Brance College Publishers.

Foster, George, 1986, Financial Statement Analysis, Second Edition, Prentice Hall International.

Gonedes, N, 1978, Corporete Signalling, External Accounting and capital market Equilibrium: Evidence on Dividends, Income, and Explanatory Items, Journal of Accounting Research, Spring.

Gujarati, Damodar N., 1995, Basic Econometrics, Third Edition, Mc Graw HaLLL, International Editions.

Hair, J.F., Anderson, R.E., Tatham R.L., dan Black, William C., 1998, Multivariate Data Analysis, Fifth 
Edition, Prentice Hal International Inc.

Harianto \& Sudomo, 1998, Perangkat dan Teknik Analisa Investasi Di Pasar Modal Indonesia, PT. Bursa Efek Jakarta.

Kusuma, Indra W., 1998. Comparing The Effects of Income Smoothing, Practices On The Earnings- Price Ratio of Japanese and Us Firms. Desertasi, Kent State University.

Leibowitz, Martin L., dan Kogelman, S., 1991, The Franchice Factor for Leveraged Firms, Financial Analysist Journal, Vol. 47, No.46, November/ December.

Mangku, I. Ketut, 2001, FaKTOR-Faktor Yang Mempengaruhi PER di BEJ, Tesis Program Pasca Sarjana UGM, Yogyakarta.
Mpaata, K.A; Sartono, Agus S., 1997. Factor Determining Price Earnings (P/E) Ratio. Kelola, No.15/VI.

Nugraheni, Bernadetta Diana, 2002, Studi Price earnings Ratio Antar Sektor Industri manufaktur, Tesis Program Pasca Sarjana UGM, Yogyakarta.

Sartono, A.: Munir, M., 1997. Pengaruh Kategori Industri Terhadap Price Earnings (P/E) Rratio Dan Faktor-Faktor Penentunya, Jurnal Ekonomi Dan Bisnis Indonesia, Vol.12, No.3.

Watts, Ross L. \& Jerold L., Zimmerman, 1986_Positive Accounting Theory, Prentice hall Inc., Englewood Cliffs, New Jersey.R 